\title{
Fiscal Decentralisation, Public Expenditure Management and Human Capital Development in Nigeria
}

\author{
Stephen I. Ocheni, Phd \\ Professor of Public Sector Accounting and Management, \\ Faculty of Management Sciences, Kogi State University \\ Anyingba, Kogi State, Nigeria \\ Michael Sunday Agba, Phd \\ Department of Public Administration, \\ University of Calabar, Calabar, Nigeria
}

Doi: 10.2478/ajis-2018-0016

\begin{abstract}
The paper focuses on fiscal decentralization, public expenditure management and human capital development in Nigeria. It presents a synergical relationship/nexus between fiscal decentralization, public expenditure management and human capital development and sees fiscal decentralization as an imperative necessity of empowering levels of government with financial resources to bring government closer to the people by the rendition of social services to people within their jurisdictions. The paper further argues that assigned fiscal responsibilities of governmental agencies must be backed up with prudent management of public expenditure (recurrent and capital) which should be aptly targeted at developing the human resources considered as the kingpin of true developmental efforts in any society. Nigeria, a social formation with an estimated population of 180 million persons and the largest economy in Africa has consistently failed in fostering the development of its human capital through budgetary allocations and implementation, fiscal decentralization and public expenditure management. To arrest the trend, the paper calls for a sustained commitment on the part of government in the development of the nation's resources through sustained budgetary allocations in education, health, agriculture, infrastructural development, training and retraining of workers, power, science and technology and execution of people oriented public programmes/projects.
\end{abstract}

Keywords: Fiscal decentralization, public expenditure, management, Human Capital Development, Budgetary Allocations

\section{Introduction/Setting the Scene}

Give me six hours to chop down a tree and I will spend the first four (hours) sharpening my axe (Abraham Lincoln cited in Deeper Life Daily Devotional Guide, vol. 4, 2017).

The expression "government is finance" underscores the essentiality of finance in the execution of the social contract existing between the government and its citizens. The social contract theory by Thomas Hobbes projects a "psychological contract and understanding" where the citizens in attempt to avoid the state of nature described by Hobbes as brutish, cruel, selfish, nasty, fearful, criminalistics and animalistic in nature surrendered their rights and authorises the state or sovereign power to provide for them essential social services that make life enjoyable and the society habitable. This explains in a theoretical sense and nutshell, the emergence of a Welfarist State where the state is mandated to intervene and play a fundamental key role in 
protecting and promoting the socio-economic well-being of its citizenry. In developing states like Nigeria, Kuwait and other oil producing states, the fast-developing phenomenon of welfare state has been tied to the discovering of oil in large commercial quantity coupled with the influence of political and social factors in the country. As Khalaf and Hammoud (1987) observed with regards to the case of Kuwait:

The causes of this fast-developing phenomenon have generally assumed to be the inevitable result of the accumulation of petro-dollar revenues and the willingness of the ruling elites to modernise their traditional societies (p. 343).

In the case of Nigeria, Ozor observed that, although, the establishment of public enterprises in the country dates back to colonial times, its rapid expansion in a large scale by the government after independence was the direct consequence of the discovery of crude oil in large quantity which empowered the state financially to intervene economically and in the provision of more essential services. To carry out its responsibilities to its citizens and society, the state has had to employ the tools of budgetary allocation, policy and public expenditure. By these tools, financial resources are allocated to the various sectors of the country through the jurisdictional mandate of the three tiers of government (the federal, state and local governments). It must be acknowledged that the efficiency and effectiveness at which fiscal resources are allocated in the state has been a serious concerned for scholars and professionals. Hence, the fashionable call (this call became so attractive and pronounced around 1950 to 1980) among scholars, professionals, politicians and policy makers to embrace and apply fiscal decentralisation, public expenditure management and the development of the human capital as a means of improving efficiency, performance of the public sector and stimulating development in the country and the world in general.

This paper is therefore an attempt to examine the performance and effect of fiscal decentralization and public expenditure management on human capital development in Nigeria. The paper shall also attempt to examine the policy options available for the country in the face of the current economic recession the country is battling with. For the purpose of exposition and understanding of the issues under disquisition, the paper is compartmentalized into sections.

\section{Presentation of Conceptual Lenses and Prism}

Our interest here is to present and clarify the following conceptual lenses and prism: fiscal decentralisation, public expenditure management and human capital development. These concepts are not new in the literature of management, accounting, public administration, and other social science disciplines; however, their clarification here will help us greatly to calve out a direction for the disquisition before us.

\section{Fiscal Decentralization}

Perhaps the best, engaging and a more rewarding approach to start the clarification of fiscal decentralisation is first consider the meaning of decentralisation. Decentralisation means in a general sense, the transfer of political and decision making power/authority from the central government to other levels of government (sub-national governments) deemed to be closer to the people. This is done with a view to improving public accountability and the capacity of the state to render social services to the people efficiently and effectively. Although, the term decentralisation is not a new concept, it however, gained attention in the 1950s and 1960s when British and French governments prepared the colonies under their jurisdictions for independence by devolving responsibilities for certain programmes to local authorities (Work, 2002). In a statement that provides an historical linkage between decentralization and development, Work (2002), noted that, in the 1980s, decentralization came to the forefront of the development agenda alongside the renewed global interest on government and human-centered approaches to human development (p.5).

Developed and developing countries which have decentralised do that for at least five contextual reasons: for western countries that have embraced the doctrine of decentralization, they adopted it as an effective mechanism for restructuring the government to render public service 
effectively in the post-welfare state" epoch (Bennett, 1990 and Widasin, 1997 cited in Ebel and Vilmaz, 2002:2). It has also been argued that developing countries who are resorting to decentralisation, do so order to overcome the challenge of ineffective and inefficient governance, macroeconomic instability and inadequate economic growth (Bird and Vaillancourt, 1999 cited in Ebel and Vilmaz, 2002). For countries in Latin America which have adopted decentralisation, did so out of the political pressure coming from the people (Rojas, 1999 cited in Ebel, 2002). On the other hand, post-communist central and eastern European countries see decentralization of the state as the consequence of the paradigm shift and transition from socialism to market economy and democracy (Bird, Ebel and Wallich, 1995 cited in Ebel, 2002). Decentralization could also be adopted as the case in some African states, for the reason of promoting national unity (World Bank, 1999), integration and development.

Decentralisation is in three forms: political decentralisation, fiscal decentralisation and administrative decentralisation. The diagram which appeared as the appendix I in this paper presents the nature of the above three forms of decentralization; and the system outcomes, results and impact that decentralisation could possibly have on the society. The diagram present decentralisation as a restructuring policy option aimed at stimulating the presence of government in terms of development at the grassroots/rural communities. In other words, decentralization is closely associated or related to "subsidiarity" which presupposes that functional tasks be assigned to the lowest level of social order deemed to possess the competence of accomplishing them (Work, 2002 \& Stohr, 2001).

Having seen the meaning of decentralisation and the possible three forms it may take in a country, what then is fiscal decentralisation? When decentralisation is qualified by the term fiscal, it is used to refer to "budgetary practices" and "resource reallocation" to state or local governments in order to improve the quality and effectiveness in the conduct of government business while expanding the authority and capabilities of sub-natural levels of government (Work, 2002; UNDP, nd). Resource allocation as a component of fiscal decentralization is often accompanied with agitations and negotiations for the building of human and institutional capacities. As Work (2006:6), pointedly observes:

Arrangements for resource allocation are often negotiated between the central and local authorities, based on several factors including interregional equity, availability of resources at all levels of government and local fiscal management capacity. Experience in fiscal decentralisation has led to capacity building in expenditure and revenue assignment as well as the design of fiscal transfer formulas and sub-national borrowing.

Basically, therefore, fiscal decentralization deals largely with the transfer of financial authority and responsibilities from the central government to other levels of government for the purpose of improving public service delivery, stimulating economic growth, engendering human capital development, and expanding effective infrastructural development. In Nigeria fiscal decentralisation is well-enshrined in the constitution of the federal republic of Nigeria. The debate, on fiscal decentralization in Nigeria has been largely centered on the need to increase the funding capacity of state and local governments in view of their inadequacy in meeting up with their financial obligations of providing public services and goods to people within their jurisdictional area of responsibility. However, the other side of the debate is that the performance of government with regards to the effective and efficient utilisation of financial resources in the provision of public services and goods is at best described as epileptic due to lack of accountability, bureaucratic bottle net, bazaar mentality and leadership challenges. Here is lies the burden of this paper which seeks to assess the Nigeria's fiscal decentralization and public expenditure management in the light of its effects on human capital development implications.

According to Khemani (2001), discussions on Nigeria's fiscal decentralisation overwhelmingly revolves around the revenue formula that allocates resources from the country's federation account amongst the three levels government -48.5 percent of the financial resources are transferred to the federal government, 24 percent to the states government, and 20 percent to the 774 local government areas. The 7.5 percent remaining is shared between derivation funds for oil and mineral producing areas, a stabilisation fund, an ecological fund, and the Federal Capital Territory FCT (Khemani, 2001:1). The position of this paper is that fiscal decentralisation has not been 
justified by the state and local government especially in salary and benefits payment, infrastructural development, human capital development and public service delivery in general. Hence, the imperativeness of the call by Nigerians for the Buhari led administration at the federal level to take up the responsibilities of paying salaries to state and local government workers as a way of guaranteeing the financial empowerment of the human resources at that level. It is important to note that the 1999 constitution of the federal republic of Nigeria and other sources assigns responsibilities and expenditure to the federal, state and local governments. These expenditure responsibilities are captured in table 1 below:

Table 1: Nigerian Expenditure Assignments

\begin{tabular}{|l|l|}
\hline $\begin{array}{l}\text { Level/tier of } \\
\text { government }\end{array}$ & Expenditure category \\
\hline Federal only & $\begin{array}{l}\text { Defense, shipping, federal trunk roads; Aviation; Railways; posts, telegraphs, and } \\
\text { telephones; police and other security services; regulation of labour, interstate commerce, } \\
\text { telecommunications; mines and minerals; social security; insurance; natural statistical } \\
\text { system; national parks, guidelines for minimum education standards at all levels; water } \\
\text { resources affecting more than one state; }\end{array}$ \\
\hline $\begin{array}{l}\text { Federal-state } \\
\text { (shared) }\end{array}$ & $\begin{array}{l}\text { Antiquities and moments, electricity; industrial, commercial and agricultural development; } \\
\text { scientific and technological research, statistics and surveys; university; technological and } \\
\text { post-primary education; health and social welfare; }\end{array}$ \\
\hline $\begin{array}{l}\text { State-local } \\
\text { (shared) }\end{array}$ & $\begin{array}{l}\text { Primary, adult and vocational education; health sources; development of agriculture and } \\
\text { non-mineral natural resources; }\end{array}$ \\
\hline $\begin{array}{l}\text { Local } \\
\text { government }\end{array}$ & $\begin{array}{l}\text { Economic planning and development; cemeteries; burial grounds, homes for the destitute } \\
\text { and infirm, markets; sewage and refuse disposal; roads, streets, street lighting, drains, } \\
\text { other public facilities. }\end{array}$ \\
\hline
\end{tabular}

Source: Khemani, Stuti (2001), "Fiscal Federalism and Service Delivery in Nigeria: The Role of States and Local Governments", p. 4; The 1999 Constitution of the Federal Republic of Nigeria and Sectoral Policy Reports.

\section{Public Expenditure Management}

Generally, public expenditure is the means through which recurrent and capital needs of the nations are addressed. It usually takes the form of recurrent expenditure which deals with government expenditure outlays fundamental for its day-to-day running. The second form that public expenditure takes is capital expenditure which refers to investment outlays of the government aimed at increasing the country's capital stock (Ukah, 2009). Over the years, the scope of government business has expanded and become complex, thus, increasing the expenditure of government and the cost of governance. For instance, the cost of governance became so much that the Obasanjo Civilian led administration in Nigeria (1999-2007), sought to reduce the cost of governance through far reaching reforms in the country's public personnel structure by rightsizing and embarking on the monetization of the fringe benefits of public servants (Agba, 2006 \& Agba, Achimugu, Chukwurah \& Agboni, 2011). In the face of this reality and the decline in government revenue as a result of the fall in crude oil price in the international market, the management of government expenditure has become imperative to promote the accomplishment of three desired outcomes: aggregate fiscal discipline; allocative efficiency and operational efficiency (Campos, 2001:1). Within this background, public expenditure management is seen as a fundamental instrument of government policy to distribute and make use of available resources productively, effectively and sensitively (Allen, Tommasi, 2001:19; Djurovic- Todorovic and Djordjevic, 2001; 2009). In specific terms, public expenditure management include among others such activities like allocation of resources through budgetary processes; managing budget implementation in a prudent and transparent manner; accounting, reporting and auditing aimed at ensuring fiscal transparency and performance measurement and evaluation. Behind, every successful and effective public expenditure management is the building of human and institutional capacity. Human 
resource management lies at the heart of improving social service delivery by means of public expenditure management. The diagram in appendix 2 of this paper captures this point and highlights the basic objectives of public expenditure management and budget management.

As already alluded to, human resource management lies at the heart of obtaining the basic objectives (aggregate fiscal discipline, allocation efficiency and technical efficiency) of public expenditure management (PEM). Each of the objectives of PEM requires a well trained and motivated human component to guarantee its accomplishment. Human resources are organizational assets vital for its effective and efficient functioning. Onah (2015) observes that human resources are usually rated higher than other resources since the management of other resources (financial, physical, information resources) largely depends on the former (p.3). In fact, the failure of any public expenditure management system is essential a failure of human resource management and human capital development. It is therefore rewarding to state that Cuming (1968:21) sees human resource management in its simplest form as obtaining the best possible staff for an organization and, having gotten them, looking after them so that they can be retained and willing to stay and give of their best to do the job for which they are employed. If we are to adopt a fiscal decentralisation that will have a positive impact on resource allocation, public service delivery, infrastructural development and socio-economic development, then the right caliber of personnel must be obtained through an effective human resource management system. However, this depends on creating conducive political, economic, social technological, physical and legal environments in which human resource management will operate and develop. This brings to the question about what human capital development as a component of human resource management.

Human capital is actually a term popularised by Jacob Mincer and Grary Becker. It refers to the human factor of an organization; the creativity, knowledge, skills, expertise, abilities of the people employed in an organization and which helps to give the organization its distinguishing characteristics (Armstrong, 2009; Bontis et al; 1999). According to Davenport (1999), workers possess innate abilities, behaviours, and personal energy and these elements constitute the human capital that is brought to the workplace.

Fiscal decentralisation that will produce the desired sustainable outcome of effective public service delivery, efficiency resource allocation and economic growth and development should be targeted at developing the human capital. The significance of human capital development in this direction cannot be over emphasized. As Armstrong (2009:78), aptly observes, "human capital theory, regards people as assets and stresses that investment of organizations (and countries) in people will generate worthwhile returns". Developing the human component of a country or an organization involves creating and cultivating enabling environments in which workers and human beings in general can readily learn and adopt new ideas, skills, behaviour, competencies and attitudes. This can be accomplished through the mechanisms of training, facilitation, coaching and consulting (Human Capital Development Group, 2017), workshops, conferences and educational programmes.

It is in the light of this that Harbison (1962) sees human capital development as the acquiring and increasing the number of persons who possess the requisite skills, experience, education and knowledge which are fundamental for economic development and growth. Fiscal decentralisation should therefore be directed at building capacity and empowering people and mobilizing productive resources for the betterment of the masses at all levels of government. In this regards, Adelakun (2011), argues that:

.... What really matters in Nigeria is the empowerment of people and the mobilisation of economic surplus into productive investment channels. There is also the need for the Nigerian economy (Nigerian government to make concerted efforts) to eliminate or minimize those constraints towards human capital development so as to enhance rapid economic growth (p. 30).

There is no better time to develop the human capital of the country than now when the country has just emerged out of recession and revenue from the oil sector is consistently dwindling. Empowering people and developing a country's human capital increases the chances of wealth creation, economic growth and development. If this is the case, it is apt to develop time in this paper to assess the human capital development strategies of the country. 


\section{Assessment of Human Capital Development Strategies in Nigeria}

The Nigerian government at federal, state and local government levels has over the years adopted a number of strategies aimed at developing the human capital that is fundamental in engendering the development of the country. An assessment of these strategies summarily shows that good intentions are sometimes not translated into reality. As noted earlier in the paper, the constitution of the Federal Republic of Nigeria recognizes and made provision for fiscal decentralisation as a means of bringing government closer to the people at the grassroots through the financial empowerment of the three levels of government. Each year, budgetary allocations are made to address sectoral needs such as education, agriculture, security, defence, aviation, infrastructure, transportation, electricity, health, power, etc. Agitations by unions like the Academic Staff Union of Universities, (ASUU), Nigeria Medical Association, etc have been on to increase government fiscal expenditure in relevant sectors of the economy.

We shall begin our evaluation of Nigeria human capital development strategies by taking a look at the country's past budgetary allocations on education. Employment in the educational sector of the country runs in millions covering academic and non-academic staff and involving both public and private educational institutions. Generally, tertiary educational institutions in Nigeria are established for the production and training of the manpower resources of the country; conduct of research, assisting in the consumption of research outputs and community service. In other words, tertiary educational institutions are to perform the tripartite functions of teaching, research and community service (Agba, 2015; Agba and Ocheni, 2017). Given the above cardinal role played by the educational sector, government's budgetary allocations date back to the colonial era. However, our interest in this paper is on selected budgetary allocations since democratic resurgence (19992015).

Let us start by looking at the 2013 budget of the Federal Republic of Nigeria. The 2013 budget of the Federal Government of Nigeria emphasized four cardinal pillars: macro-economic stability, structural reforms in key sectors of the country, governance and institutions and investment in critical sectors of the country. These pillars were actually a continuation of the four pillars emphasized in the 2012 budget. The financial provision for human capital development in the 2013 budget in the area of education and health was N705 billion. Other allocations provided in the 2013 appropriate Act are N387.97 billion for statutory transfers; N591.76 billion for debt service; N1.62 trillion for capital expenditure; N2.38 trillion for recurrent (Non-Debt) Expenditure consisting of 1.1717 trillion for personnel cost and N208.9 billion as overhead cost. N180 billion was budgeted for the provision of social safety net schemes; maternal and child healthcare, youth development and vocational training of Nigerians (Okorijo-Iweala, 2013).

A critical look at the above budgetary allocations reveals that the government made some effort in developing the human capital of the country through the education, health and infrastructural development of the economy. However, government efforts are deemed inadequate in view of the pressing demand coming from the educational and health sectors of the country. Across the country, the efforts of the federal government were complemented by budgetary provisions of states and the 774 local governments in the country. Again these complementary efforts are deemed inadequate compared to expectations. Acknowledging this inadequacy, Abdallah (2016), observes that:

The federal and state governments will spend less than 9 percent of their total budgets of 12.2 trillion on education this year (2016), despite their publicised commitments toward the sector.

Available budgetary statistics depict that in 2016, N653.53 billion (10.70\%) of the total budget of 6.1 trillion of the 33 states in the country was provided for education. This figure is below the 26 percent benchmark prescribed by UNESCO on the educational sector (Abdallah, 2016). The figure below provided by Abdallah (2016) further shows the 2016 budgetary allocations on education in terms of the federal government and the six geopolitical zones of the country. In 2016, a total of N1.02 trillion was spent by the Federal government and the six geopolitical zones of the country. While the federal government spent 368 billion Naira on the educational sector the six geopolitical zones spent as follows on education: South-South (N101 billion); South-East (N 13 billion); South West (N 178 billion); North Central (N 102 billion); North East (N85 billion) and North West (N174 
billion) (Abdallah, 2016). It is our considered opinion that effective implementation of the budget despite the seemly inadequate provisions will add value to the human capital development of the country.

The Federal Government in 2014 showed a greater commitment to developing the human capital of the country through budgetary provisions of 493.45 billion Naira on education (10.6\% of the total budget) and 262 billion Naira (1.7 billion USD) on health which constitute about $6 \%$ of the national budget of the country for 2014 (Inekweazu, 2013). These budgetary provisions fell short of the global prescribed expectations of $15 \%$ of a country's budget to be spent on health and $26 \%$ UNESCO's benchmark on education (Ihekweazu, 2013; PWC, 2014). Public expectations from government for the health, education and other sectors of the country are high and demands for annual increase of financial allocation are on the increase. Actual increase and mounting expectations will make no meaning if allocations are not match with prudent use of budgeted resources and transparent accountability shown by governmental institutions. This is what the Buhari's administration desire to achieve when President Buhari stated that his government will ensure that every kobo budgeted for counts.

It is important to also note that the 2014 budget which was named "a budget for job creation and inclusive growth" focused attention on manpower empowerment for job creation, infrastructural development, regulating cost of governance, supporting industry and creating a conducive environment for doing business (Okogu, 2014). To provide a security and friendly environment, the defence sector that year gulped 968.127 billion Naira (i.e. $20 \%$ of the total budget estimated at N4.962 trillion). Government also made provision of N268.37 billion for Subsidy Reinvestment and Empowerment Programme, SURE-P. It will be recalled that the Subsidy Reinvestment and Empowerment Programme (otherwise known as SURE-P) was a scheme established by the Federal Government of Nigeria under the leadership of the then President of the country, President Goodluck Ebele Jonathan. The scheme was initiated on January, 2012, with the goal of re-investing the savings arising from fuel subsidy removal on critical infrastructure projects, social safety net programmes and creates employment through internship programs for unemployed graduates in the country. The internship scheme was meant to serve as a tool for human capital development through the acquisition of fundamental job skills. The task of combating unemployment and poverty is a national concern and one that has engaged the policy agenda of government but with less encouraging results of government performance given the mounting problem of unemployment and poverty (Onah, 2012; Umobon and Ekong, 2015; Abu, 2015).

Statistics for 2015 and 2016 budgetary allocations of the Federal Government of Nigeria show a budgetary allocation of N492.034 billion on education in 2015; N369.6 billion on education in 2016. The health sector in 2015 and 2016 respectively gulped 237 billion (about 5.5 percent of the total budget of 4.36 trillion in 2015) and N221.7 billion (Odunsi, 2015; Otaru and Nwaosu, 2015). The 2016 budget of the federal government which is titled budget of change was presented with a determination to prudently utilize it financial provisions. This is captured in the President Buhari statement during the presentation of the budget proposal to the National Assembly:

This budget (2016) will ensure that every kobo spent by government counts; we will devote a significant portion of our current expenditure to institutions that provide government services... Nigerians must be part of the growth story. Our government shall deliver on security, jobs and infrastructure; it is the right of all Nigerians (Vanguard, December 22, 2015).

A look at the above words shows president's concern to better the lots of Nigerians and develop the human capital of the country through prudent financial usage and management. This is demonstrated in his fight against corruption in the public sector of the country. We therefore submit that, it is not enough to make budgetary provisions as is annually done in federal, state and local government budgets, but that such budgetary provisions must be prudently utilised to bring about the development of the human capital and other sectors of the country.

There are other strategies which also demonstrate government commitment in developing the human capital of the country. These strategies are the training and retraining of staff, sponsorship of conferences, workshops and support for staff development and research undertakings. On annual basis, government budget for the above as a means of developing its human resources for competitive advantage. For instance, the federal government through the Tertiary Education Trust 
Find (TETFUND) has consistently supported infrastructural development in federal and state owned tertiary educational institutions (Universities, Polytechnics, Colleges of Education and Minotechnics); staff development of academic and non-academic staff (through sponsorship of post graduate programmes of staff in Nigeria and abroad); issuance of research grants to well deserving proposals submitted by a team of academic staff; grants to staff to publish books and journals; etc. Such interventions though not enough, have actually made significant impact in the development of public educational institutions. To say the least, the TETFUND has in a way provided "focused and transformation intervention in public tertiary institutions in Nigeria through funding and effective management (www.tetfund.gov.ng/index.php/2-uncategorised/3-our mission).

\section{Conclusion}

The idea behind fiscal decentralisation is not bad. However, the possibility of its abuse by governmental agencies through poor public expenditure management hampers the development of the country's human capital. Because of the importance of human capital development, it important not compromise budgetary expenditure in such sectors like education, health, transport, infrastructure, training and staff development, research development, agriculture, etc. Building capacity in these sectors is one of the means of guaranteeing the socio-economic development of the country and the delivery of democratic dividends to Nigerians.

\section{References}

Abdallah, Nuruddeen M. (June 3, 2016). "FG States spend 8\% of Budgets on Education" .Daily Trust,www.dailytrust.com.ng/news/general/fg-states-spend-8-of-budgets-on-education/149521.html. Retrieved on $6 / 12 / 17$

Abu, Christian Ukeame (2015). Subsidy Reinvestment and Empowerment Programme (SURE-P) and Employment Generation in Nigeria (2012-2014). Master of Science thesis submitted to the Department of Political Science, Faculty of Social Sciences, University of Nigeria, Nsukka, December 2015.

Adelakun, O. J. (2011). Human Capital Development and Economic Growth in Nigeria, European Journal of Business and Management 3 (9): 29-38.

Agba, M.S.( Jan., 2015). Electric Power Supply and Work Performance of Academic Staff in Nigerian Universities: A Synergy Analysis. Indian Journal of Commerce and Management Studies, 4(1): 33-44.

Agba, M.S., Achimugu, H.,Chukwurah, D.C.J., Agboni, J.U. (2012). Reward System in the Nigerian Political and Public Sector: The Call for a Paradigm Shift in the $21^{\text {st }}$ Century. International Journal of Learning and Development,2(5):77-85.

Agba,M.S. (April,2006). The Monetization Policy of Federal Government of Nigeria and its Implication for Workers Productivity and Governance. Sophia: An African Journal of Philosophy,8(2).77-83

Agba, M.S. \& Ocheni, S. I. (2017). An Empirical Study of the Effects of Work Environment (Electric Power Supply) on Job Performance of Academic Staff in Nigerian Public and Private Universities. Higher Education of Social Science (12(1): 11-20

Allen, Richard and Tommasi, Daniel (2001). Managing Public Expenditure: A Reference Book for Transition Countries, SIGMA: OECD.

Armstrong, Michael (2009). Armstrong's Handbook of Human Resource Management Practice $11^{\text {th }}$ Edition, London: Kogan Page.

Bontis, N., Dragonetti, N. C. Jacobsen, K. And Roos, G. (1999). The knowledge toolbox: A review of the tools available to measure and manage intangible resources". European Management Journal, 17 (4), pp. 391402.

Campos, J. Edgardo (2001). What is Public Expenditure Management (PEM)? The Governance Brief: A Quarterly publication of Asian Development Bank, Issue I (pp. 1-4).

Cuming, M. W. (1968). The Theory and Practice of Personnel Management, New York: McGraw Hill Book Company.

Djurovic-Todorovic, J. \& Djordjevic, Marina (2009). The Importance of Public Expenditure Management in Modern Budget System, Facta Universitatis Series: Economics and Organization, 6 (3): 281-294.

DLBC (2017). Daily Manna: A Daily Devotional Guide. Vol. 4, Lagos: Life Press Ltd.

Harbison, F. H. (1962). Human Resources Development Planning in Modernising Economies. International Labour Review (pp. 453-458).

Human Capital Development Group (2017). Human Capital Development:Global Business perspective, cultural sensitivity. Available at www.thhcdgroup. com. 
Ihekweazu, Chikwe (2013). "Analysis of Nigeria's Budget for Health in 2014". Nigeria Health Watch, Retrieved from nigeriahealth watch.com/analysis-of-nigeria-budget-for-health-in-2014 on 5/12/17.

Khalaf, Sulayman \& Hammoud Hassan (1987). The Emergence of the Oil Welfare State: The Case of Kuwait. Dialectical Anthropology 12 (3): 343-357.

Odunsi, Wale (2015). "2016 Budget: Breakdown of sums allocated to Presidency, MDAs, others". Daily Post, December 26, 2015.

Okogu, Bright (2014). "A Broad Analysis of the 2014 FGN Budget". A presentation at the ICAN symposium on the 2014 Budget, Tuesday, 15, July, 2014.

Okonjo-Iweala, Ngozi (2013). "Overview of the 2013 Budget". Premium Times, March 8, 2013.

Onah, Fab O. (2015). Human Resource Management, $4^{\text {th }}$ Edition, Nsukka: University of Nigeria Press Ltd.

Onah, V. C. (2012). Politics of Youth Empowerment and Poverty Reduction in Nigeria. Education and Training 37, 13-17.

Otan, Anthony and Nwaosu, Beta (2015). "Stakeholders seek 15\% Budgetary Allocation for Health Sector" in Nigeria. The Guardian, 28 May 2015.

Ukah, O. C. (2009). Government Expenditure Management and Control within the framework of Ethiopian Economy, African Research Review: An International Multidisciplinary Journal 3 (1): 206-213.

Umobon, E. \& Ekong, U. (2015). Employment Generation for a small Economy: The Nigerian Case. International Journal of Interdisciplinary and Multidisciplinary Studies, 2 (93-103).

Vanguard (2015). "2016 Budget: FG to spend 221.7bn on Health Sector". Vanguard, December 22, 2015.

Work, Robert (July 2002). Overview of Decentralization Worldwide: A Stepping Stone to Improved Governance and Human Development. Being a paper presented at the $2^{\text {nd }}$ International Conference on Decentralization with the theme Federalism: The future of Decentralising States 25-27 July, 2002, Manila, Philippines, UNDP (pp. 1-20).

World Bank (1999). World Development Report 1999/2000. Entering the $21^{\text {st }}$ Century. New York: Oxford University press.

\section{Appendix 1}

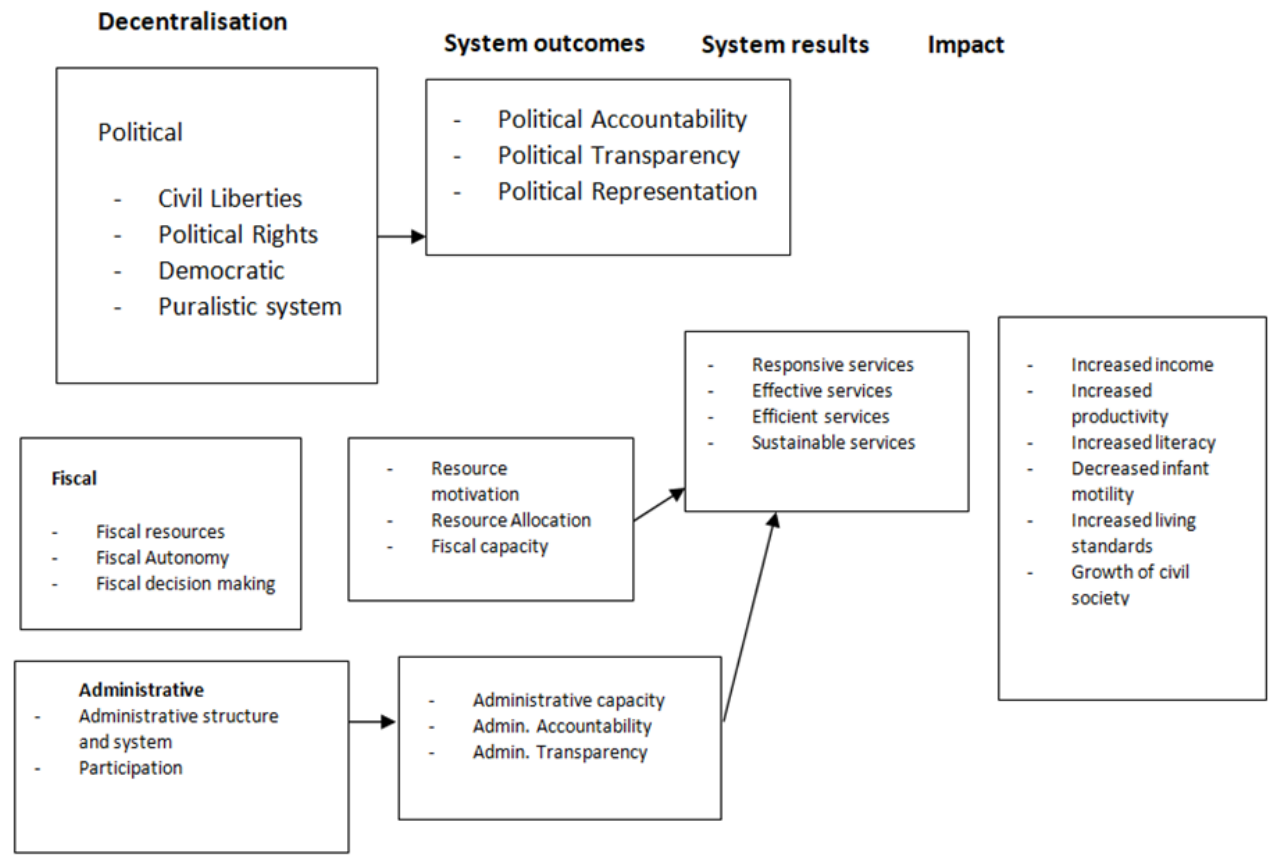

Figure 1: Decentralisation and its consequential impact on three fronts

Source: Adapted with slight modification from Parker, Andrew N. (1995). Decentralisation:The Way Forward for Rural Development, Policy Research paper 1475. Washington, DC: The World Bank 


\section{Appendix 2}

\section{Basic Objectives}

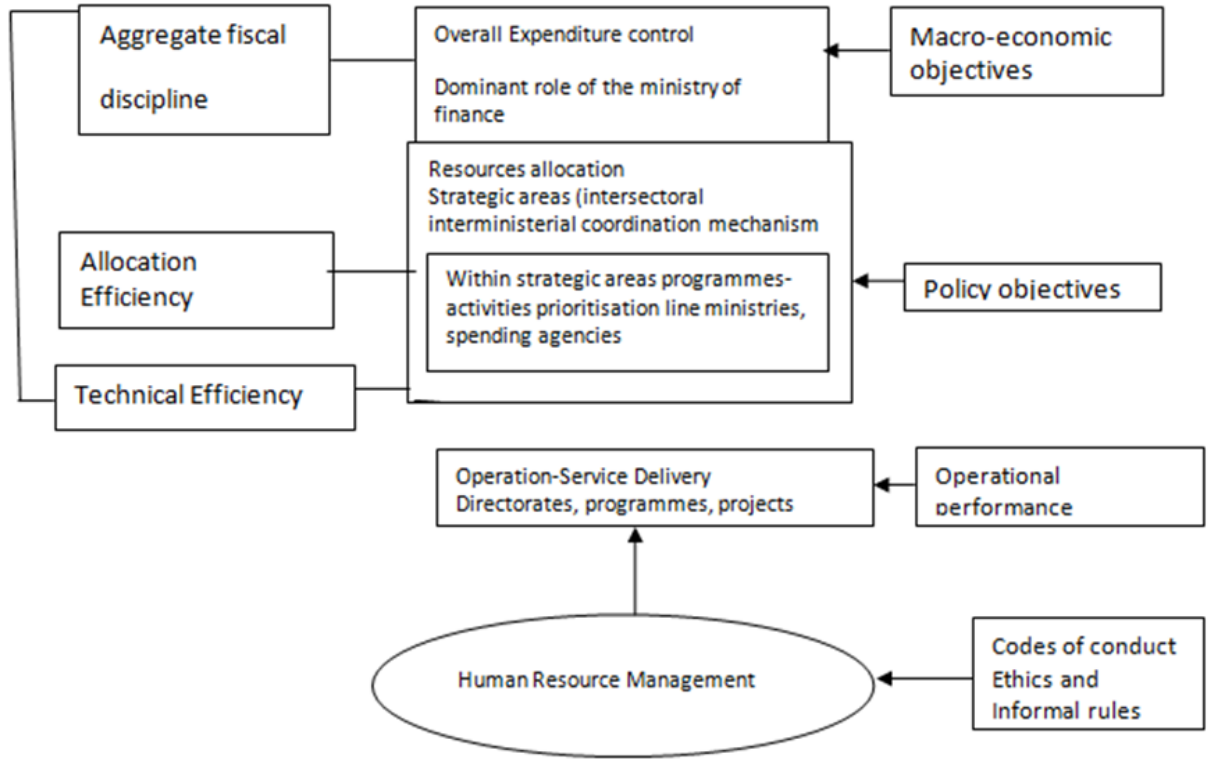

Source: Allen, Richard and Tommansi, Daniel (2001). Managing Public Expenditure: A Reference Book for Transition Countries, p. 20. 